\title{
Environmental sanitation conditions and health impact: a case-control study
}

\author{
Condições de saneamento ambiental e impacto na saúde: \\ um estudo caso-controle
}

\author{
Léo Heller ${ }^{1}$, Enrico Antonio Colosimo ${ }^{2}$ and Carlos Mauricio de Figueiredo Antunes ${ }^{3}$
}

\begin{abstract}
This epidemiological investigation examines the impact of several environmental sanitation conditions and hygiene practices on diarrhea occurrence among children under five years of age living in an urban area. The case-control design was employed; 997 cases and 999 controls were included in the investigation. Cases were defined as children with diarrhea and controls were randomly selected among children under five years of age. After logistic regression adjustment, the following variables were found to be significantly associated with diarrhea: washing and purifying fruit and vegetables; presence of wastewater in the street; refuse storage, collection and disposal; domestic water reservoir conditions; feces disposal from swaddles; presence of vectors in the house and flooding in the lot. The estimates of the relative risks reached values up to 2.87 . The present study revealed the feasibility of developing and implementing an adequate model to establish intervention priorities in the field of environmental sanitation.
\end{abstract}

Key-words: Diarrhea. Hygiene practices. Model for priority setting. Urban refuse. Water supply.

Resumo Esta investigação epidemiológica estuda o impacto das condições de saneamento ambiental e de práticas higiênicas sobre a ocorrência de diarréia entre crianças menores de 5 anos, residentes em uma área urbana. O delineamento caso-controle foi utilizado; 997 casos e 999 controles foram incluidos na investigação. Casos foram definidos como crianças com diarréia e controles foram selecionados, aleatoriamente, entre crianças com menos de 5 anos. Após ajustamento (regressão logística), as seguintes variáveis foram detectadas como significativamente associadas à diarréia: lavar e higienizar frutas e vegetais; presença de água de esgoto na rua; coleta, armazenagem e disposição do lixo; condições dos reservatórios domésticos de água; disposição das fezes de fraldas, presença de vetores nas casas e inundação do lote da casa. As estimativas pontuais do risco relativo alcançaram valores até 2,87 . O presente estudo mostra a factibilidade de desenvolvimento e implementação de modelos adequados para estabelecer prioridades de intervenção no campo do saneamento ambiental.

Palavras-chaves: Abastecimento de água. Diarréia. Lixo urbano. Modelo para estabelecer prioridades. Práticas higiênicas.

Although the World Bank ${ }^{46}$ had discouraged the development of investigations involving environmental sanitation conditions and health impact from the mid 1970's, studies concerning these associations have been receiving increased attention since the beginning of the 80's.

In 1983, Blum \& Feachem ${ }^{6}$ stated that most of the studies published until then had methodological limitations. These constraints were identified as from one to more than eight methodological flaws and, in several of the 44 studies reviewed, the results obtained could not be considered unbiased.
In the same year, a workshop on this subject was held in Bangladesh ${ }^{8}$ and, as conclusion of the discussions, the implementation of epidemiological studies on water supply and sanitation exposure was again recommended, provided that some important methodological care was observed. In order to increase the applicability of those studies, the workshop suggested the case-control design as the most adequate epidemiological method and child diarrhea morbidity as the health variable to be measured.

More than 250 studies have been carried out to investigate the probable association of environmental

\footnotetext{
1. Departmento de Engenharia Sanitaria e Ambiental da Escola de Engenharia da Universidade Federal de Minas Gerais. 2. Departmento Estatística do Instituto de Ciências Exatas da Universidade Federal de Minas Gerais. 3. Departmento de Parasitologia do Instituto de Ciências Biológicas da Universidade Federal de Minas Gerais, Belo Horizonte, MG.

Address to: Dr. Carlos M.F. Antunes. Depart ${ }^{\circ}$ de Parasitologia/ICB/UFMG. Caixa Postal 486, 31290-901 Belo Horizonte MG, Brasil

Tel 55-31-3499-2860

e-mail:antunesc@mono.icb.ufmg.br

Recebido para publicação em 22/10/2001
} 
sanitation and health conditions. The following main features were observed from the analysis of 256 epidemiological studies published in the literature ${ }^{23}$ : a) Fifty-seven (146) percent of the studies were developed on Asian ${ }^{31}$ or African ${ }^{32}$ scenarios and this tendency has not changed over the last decades; b) Seventy-seven (198) percent of the studies investigated exposure related to water supply ${ }^{34}$ and fortytwo (107) percent, aspects related to domestic wastewater disposal22. Few investigations analyzed other environmental sanitation conditions, such as refuse disposal ${ }^{18}(2 \%, 4)$, hygiene habits $5(17 \%, 44)$ or drainage, vector presence ${ }^{42}$ and other forms of exposure $(5 \%, 12)$. In the majority of cases, only rural areas were investigated ${ }^{34}$; c) Forty-one (105) percent of the studies adopted diarrhea morbidity ${ }^{9}$ as the health variable; (d) Case-control designs began to be employed in the last decade. In the universe of studies analyzed, prospective ${ }^{2}(25 \%, 64)$ and cross-sectional ${ }^{30}$ $(21 \%, 53)$ designs predominated.

The present paper describes an epidemiological case-control study, which attempts to explore some aspects of the epidemiological methodology insufficiently investigated, which could be applied to environmental sanitation exposure, such as: (a) the applicability of the case-cohort or inclusive design ${ }^{38}$, in which controls are chosen, as a random sample, among the population from where the corresponding cases are identified; (b) an investigation conducted in an urban area outside African or Asian environment; (c) the inclusion of a large set of environmental conditions, as multicategorical variables and (d) a test of sample sizes adequacy, suitable for generalizing to other similar sanitary and environmental situations.

\section{MATERIAL AND METHODS}

Studied area. The study was conducted in the urban area of Betim, a city with about 160,000 inhabitants. Betim is an industrial city, located in the Metropolitan Region of Belo Horizonte, the capital of Minas Gerais State, southeast Brazil, with a population of nearly 3.5 million inhabitants. A public concessionaire is responsible for the water supply and sanitation services. Other environmental sanitation services, for instance refuse collection and disposal, urban drainage and vector control are directly provided by the municipality.

Sample size. Considering the methods of sample size determination for independent case-control designs ${ }^{40}$ and for multicategorical exposures ${ }^{7}$, a sample size of about 1,000 cases and equal numbers of controls was considered as adequate, assuming: 1 ) probability of type I error (alpha value) $=0.05 ; 2$ ) power of the test $=0.90$ (probability of type II error (beta value) $=0.10$ ); 3 ) the prevalence of the exposure factors among the controls $\left(p_{0}\right)$ to be equal 0.30 , the lowest among the various factors being analyzed and 4 ) the minimum significant difference $(\boldsymbol{\Delta})$ between exposure factors prevalence among cases $\left(p_{1}\right)$ and controls $\left(p_{0}\right)$ equal to 0.10 .

Questionnaires. A standardized protocol was developed, with the technical assistance of Universidade Federal de Minas Gerais faculty members, specialists in sanitary engineering, epidemiology, biostatistics and sociology. The questionnaire was based on information derived from other published investigations. In addition, a large spectrum of variables related to environmental sanitation was included. After a pilot test, the final version of the protocol was defined, including 80 closed questions, organized through the following sections: 1) informed consent; 2) identification of residents in the selected houses; 3) participant identification; 4) socioeconomic status of selected families; 5 ) household characteristics; 6) water supply and individual hygiene habits; 7) wastewater disposal and existence of nearby streams; 8) domestic refuse storage and disposal; 9) rainwater flooding and pounding; 10) vector presence; and 11) validation of collected information (in loco observation).

Case selection. A case was defined as a child under five years of age, resident in Betim urban area, attended at a local health institution, whether public or private, with a report of diarrhea. The attendant physician diagnosis of diarrhea was assumed as the case definition. All local health institutions, including 15 public and 14 private health centers, were investigated. All cases diagnosed between December 20,1993 and April 4, 1994 were included in the study, comprising a final sample of 997 cases.

Control selection. In coherence with the casecohort or inclusive design definition, control was selected as a child under five years of age, randomly chosen from the resident population universe of the urban area of Betim. The control selection was based on a random allocation of houses, taken from a register used by the municipality with the purpose of housing taxes. For the allocation, algorithms for the register pages and lines were employed, using random numbers generated by a TurboBasic compiler.

While conducting the study, when the assigned house did not have a resident child under five years of age, displacement to the house on the left was adopted. For other situations, when the selection was not possible, other standardized criteria were established. For instance, when 1) the assigned house was selected twice from the allocation lists;2) the assigned house was located outside of the studied area, or 3) no houses in the selected city block had a child under five years even after adoption of the left displacement criterion, another address was randomly chosen from the original register list.

The 999 selected controls were interviewed from November 23, 1993 to April 22, 1994; the majority of the data was collected before December 18, 1993.

Interviews. The interviews were carried out by a team of ten trained interviewers, recruited among local residents familiar with this kind of activity. The conduction 
of Interviews in the same region in which the interviewer resides was avoided. Double-masked interviews were planned, but in some situations the participant status was obvious for the respondent. Information from the questionnaires was coded and introduced in a database, developed with the aid of the software MS-Access for Windows ${ }^{26}$. All data was double-entered.

Reliability test. In a sub-sample (10\% from the original sample), reliability tests were performed, through re-interviews. Four groups were defined: a) Group 1, cases/same interviewer; b) Group 2, cases/other interviewer; c) Group 3, controls/same interviewer and (d) Group 4, controls/other interviewer. The statistical analysis considered the values of the kappa statistics ${ }^{20}$.

Data analysis. The data analysis was developed through a sequence of steps, when several associations and confounding factors had progressively been identified. The data set was organized using the software MS-Excel 4 for Windows ${ }^{41}$ and statistically analyzed through the software SYSTAT ${ }^{21}$, EPIINFO ${ }^{22}$ and MULTLR $^{23}$. The sequence of the statistical analysis followed these steps: 1) frequency distribution; 2) univariate analysis, including: a) point estimate and confidence interval for the relative risk (Cornfield method $^{40}$ ), b) trend analysis (Mantel method ${ }^{40}$ ) and c) point estimate and confidence interval for the attributable risk ${ }^{40}$; 3) bivariate analysis, with inspection of potential confounders and effect modifiers (Mantel-Haenszel method $^{33}$ ); 4) multivariate analysis, using the logistic regression model ${ }^{25}$ following the sequence: a) preliminary selection of variables, from the univariate analysis $(p<0.25)^{36}$; b) intermediate logistic models construction, using 8 different homogeneous subgroups (familiar structure, socioeconomic variables, hygiene practices, water supply, sanitation, urban refuse disposal, drainage, vectors presence). Variables attaining a significance level of $p<0.15$ were kept in these models; c) final model construction, maintaining only those variables reaching significance of $p<0.05$ and d) effect modification analysis, under the multiplicative model. Variables known to be associated with diarrhea were kept in the model throughout the analysis, even when they did not reach the established significance levels.

\section{RESULTS}

Approximately $29 \%$ of identified cases were lost for interviewing; the main reason was the impossibility of localizing the address given at the participating clinics. Regarding the temporal pattern of cases distribution, it was found not to be associated with any meteorological event, such as air temperature or daily precipitation. Controls were found to be uniformly spread throughout the sixty-six Betim metropolitan regions; the proportion of controls per occupied house was also found to be evenly distributed in Betim.

Table 1 shows the frequency distribution, as well as the results of the univariate analysis for the socioeconomic and familial structure qualitative variables, with the respective relative risk (RR) and its $95 \%$ confidence interval. Trend analysis results for the polychotomous variables are also presented. Except for gender and for person who takes care of the child, all other variables analyzed, reflecting a lower socioeconomic family status or a disrupted familiar structure, were statistically associated with diarrhea. All polychotomous variables showed a strong linear increase in the risk of disease with increasing levels of exposure.

Table 2 shows the comparison of quantitative variables between cases and controls. Student's t-test demonstrated differences between these groups, except for the variable duration of breast feeding. Younger mothers and children, and variables reflecting lower socioeconomic status were found to be associated with diarrhea occurrence.

In Table 3, crude RRs for the main exposures (converted to dichotomous variables), as determined in the univariate analysis, are presented, together with the respective $95 \%$ confidence interval.

After the multivariate adjustment, several of the variables significantly associated with diarrhea, based on the crude RR, lost their significant effect. The remaining variables, in general, showed a smaller point estimate of that risk as can be seen on Table 4 .

Twenty-eight controls were later selected as cases. This identification allowed a verification of the differences between the estimates of the relative odds (RO), obtained by simulation of a traditional case-control study and the correspondent RR. The simulation was done through the exclusion of these 28 cases from the control group. The results showed a rigorous similarity between both risk measures.

Finally, the results of the reliability test indicated that $46 \%$ of the questions presented an almost perfect or substantial concordance; the remaining questions had regular, poor, or no concordance at all, according to Landis and Koch criteria for interpreting the kappa index ${ }^{29}$. In general, questions related to personal habits or daily observations had the worst index of reliability than those regarding house and family descriptions.

\section{DISCUSSION}

Although the case-control design was used, the risk measure used throughout the study was the $R R$ instead of the $R O$. This is conceptually supported by the sampling scheme employed for control identification, characterizing the case-cohort or the inclusive variant of the case-control method ${ }^{3827}$.

Cases and controls were identified from the same population. Residence in Betim urban area was an 
Table 1 - Frequency distribution, crude $R R$ and $O^{2}$ test of socioeconomic and familial structure (qualitative variables)

\begin{tabular}{|c|c|c|c|c|c|c|}
\hline \multirow[t]{2}{*}{ Variable*a } & \multicolumn{2}{|c|}{ Case } & \multicolumn{2}{|c|}{ Control } & \multirow[t]{2}{*}{$\operatorname{RR}(95 \% \mathrm{Cl})^{\mathrm{b}}$} & \multirow[t]{2}{*}{$p^{d}$} \\
\hline & $n^{0}$ & $\%$ & $\mathrm{n}^{\circ}$ & $\%$ & & \\
\hline \multicolumn{7}{|l|}{ Mother lives with the child } \\
\hline no & 23 & 2.31 & 10 & 1.00 & 2.33 & $<0.05$ \\
\hline yes & 974 & 97.69 & 989 & 99.00 & $(1.05-5.26)$ & \\
\hline \multicolumn{7}{|l|}{ Does the father live with child? } \\
\hline no & 161 & 16.16 & 125 & 12.53 & 1.35 & $<0.05$ \\
\hline yes & 835 & 83.84 & 873 & 87.47 & $(1.04-1.75)$ & \\
\hline \multicolumn{7}{|l|}{ Number of children under 5} \\
\hline 1 & 604 & 60.58 & 757 & 75.78 & $1.00[1]$ & \\
\hline 2 & 331 & 33.20 & 219 & 21.92 & $1.89[2]$ & $<0.001$ \\
\hline 3 & 52 & 5.22 & 21 & 2.10 & $3.10[3]$ & (3) \\
\hline 4 or more & 10 & 1.00 & 2 & 0.20 & $6.27[4]$ & \\
\hline \multicolumn{7}{|l|}{ Birth order } \\
\hline first & 730 & 73.22 & 886 & 88.69 & $1.00[1]$ & $<0.001$ \\
\hline second & 235 & 23.57 & 102 & 10.21 & $2.80[2]$ & (3) \\
\hline third or more & 32 & 3.21 & 11 & 1.10 & $3.53[3]$ & \\
\hline \multicolumn{7}{|l|}{ Gender } \\
\hline male & 527 & 52.86 & 502 & 50.25 & 1.11 & $>0.05$ \\
\hline female & 470 & 47.14 & 497 & 49.75 & $(0.93-1.33)$ & \\
\hline \multicolumn{7}{|l|}{ Place where child spends the day } \\
\hline at home & 929 & 93.18 & 909 & 91.08 & $2.23(1.38-3.61)$ & \\
\hline at nursery, partial time ${ }^{(2)}$ & 28 & 2.81 & 61 & 6.11 & 1.00 & 0.001 \\
\hline at nursery, full time & 40 & 4.01 & 28 & 2.81 & $3.11(1.53-6.36)$ & \\
\hline \multicolumn{7}{|c|}{ Person who takes care of the child } \\
\hline mother & 843 & 84.55 & 829 & 83.07 & & \\
\hline father & 11 & 1.10 & 13 & 1.30 & - & $>0.05$ \\
\hline other & 143 & 14.34 & 156 & 15.63 & & \\
\hline \multicolumn{7}{|l|}{ Mother education } \\
\hline complete high school or & 88 & 8.97 & 184 & 18.79 & $1.00[11]$ & \\
\hline higher & 36 & 3.67 & 54 & 5.52 & $1.39[7]$ & \\
\hline incomplete high school & 87 & 8.87 & 144 & 14.71 & $1.26[4]$ & $<0.001$ \\
\hline complete primary school & 731 & 74.52 & 583 & 59.55 & 2.62[2] & (3) \\
\hline incomplete primary school & 14 & 1.43 & 7 & 0.72 & $4.18[1]$ & \\
\hline read and or write & 25 & 2.55 & 7 & 0.72 & $7.47[0]$ & \\
\hline \multicolumn{7}{|l|}{ does not read nor write } \\
\hline \multicolumn{7}{|l|}{ Father education } \\
\hline complete high school or & 69 & 8.32 & 167 & 19.49 & $1.00[11]$ & \\
\hline higher & 29 & 3.50 & 56 & 6.53 & $1.25[7]$ & \\
\hline imcomplete high school & 101 & 12.18 & 147 & 17.15 & $1.66[4]$ & $<0.001$ \\
\hline complete primary school & 599 & 72.26 & 481 & 56.13 & $3.01[2]$ & (3) \\
\hline incomplete primary school & 15 & 1.81 & 4 & 0.47 & $9.08[1]$ & \\
\hline read and or write & 16 & 1.93 & 2 & 0.23 & $19.36[0]$ & \\
\hline does not read nor write & & & & & & \\
\hline
\end{tabular}


Table 1 - Continue.

\begin{tabular}{|c|c|c|c|c|c|c|}
\hline \multirow[t]{2}{*}{ Variable ${ }^{\star a}$} & \multicolumn{2}{|c|}{ Case } & \multicolumn{2}{|c|}{ Control } & \multirow[t]{2}{*}{$\mathrm{RR}(95 \% \mathrm{Cl})^{\mathrm{b}}$} & \multirow[t]{2}{*}{$p^{c}$} \\
\hline & $\mathrm{N}$ & $\%$ & $\mathrm{~N}$ & $\%$ & & \\
\hline \multicolumn{7}{|l|}{ Mother religion } \\
\hline any religion & 940 & 94.95 & 960 & 98.87 & 4.64 & $<0.001$ \\
\hline no religion & 50 & 5.05 & 11 & 1.13 & $(2.32-9.50)$ & \\
\hline \multicolumn{7}{|l|}{ Father religion } \\
\hline any religion & 801 & 94.12 & 845 & 98.14 & 3.30 & $<0.001$ \\
\hline no religion & 50 & 5.88 & 16 & 1.86 & $(1.81-6.08)$ & \\
\hline \multicolumn{7}{|l|}{ House ownership $^{d}$} \\
\hline score 3 & 35 & 3.56 & 78 & 8.20 & 1.00 & \\
\hline owner (score 2) & 345 & 35.06 & 385 & 40.48 & 2.00 & \\
\hline bonded (score 1) & 105 & 10.67 & 152 & 15.98 & 1.54 & $<0.001$ \\
\hline invasion, arrested or rented & & & & & & (3) \\
\hline (score 0) & 499 & 50.71 & 336 & 35.33 & 3.31 & \\
\hline \multicolumn{7}{|l|}{ Toilet existence } \\
\hline more than one (one inside) & 68 & 6.82 & 163 & 16.32 & $1.00[2]$ & \\
\hline one, inside & 680 & 68.20 & 702 & 70.27 & $2.32[1]$ & $<0.001$ \\
\hline one, outside & 201 & 20.16 & 119 & 11.91 & $4.05[0.5]$ & (3) \\
\hline ooes not have & 48 & 4.81 & 15 & 1.50 & $7.67[0]$ & \\
\hline \multicolumn{7}{|l|}{ Kitchen existence } \\
\hline no & 259 & 25.98 & 104 & 10.43 & 3.01 & $<0.001$ \\
\hline yes & 738 & 74.02 & 893 & 89.57 & $(2.34-3.89)$ & \\
\hline \multicolumn{7}{|l|}{ TV ownership } \\
\hline more than one (one in colors) & 48 & 4.82 & 121 & 12.11 & $1.00[3]$ & \\
\hline one in colors & 381 & 38.25 & 510 & 51.05 & $1.88[2]$ & $<0.001$ \\
\hline one black and white & 337 & 33.84 & 236 & 23.62 & $3.60[1]$ & (3) \\
\hline no & 230 & 23.09 & 132 & 13.21 & $4.39[0]$ & \\
\hline
\end{tabular}

*did not know the answer and refusals, when comprising less than $10 \%$ of answers, were excluded from Table

a (1) category with proportion of cases significantly higher. (2) category with proportion of cases significantly lower.

${ }^{b}[$ ] attributed score, trend analysis.

c (3) p value, trend analysis.

done unity added to score, when family owned another house.

Table 2 - Frequency distribution and mean differences (Student $t$-test) of socioeconomic and familial structure (quantitative variables).

\begin{tabular}{|c|c|c|c|c|c|c|}
\hline \multirow[t]{2}{*}{ Variables } & \multicolumn{2}{|c|}{ Cases } & \multicolumn{2}{|c|}{ Controls } & \multirow[t]{2}{*}{$t$} & \multirow[t]{2}{*}{$p$} \\
\hline & $\mathrm{n}^{\circ}$ & mean & $\mathrm{n}^{\circ}$ & mean & & \\
\hline Mother's age (years) & 997 & 26.99 & 999 & 29.21 & -6.83 & $<0.001$ \\
\hline Number of children under 5 living in the house & 997 & 1.47 & 999 & 1.27 & 7.72 & $<0.001$ \\
\hline Child's age (years) & 997 & 1.72 & 999 & 2.63 & -15.86 & $<0.001$ \\
\hline Mean age of children under 5 (years) & 997 & 1.89 & 999 & 2.53 & -12.24 & $<0.001$ \\
\hline Number of persons living in the house & 996 & 4.97 & 998 & 4.71 & 2.93 & $<0.01$ \\
\hline Number of rooms & 996 & 4.67 & 996 & 5.68 & -11.28 & $<0.001$ \\
\hline Person/room & 995 & 0.95 & 995 & 0.75 & 10.60 & $<0.001$ \\
\hline Income (minimum salary) & 728 & 2.56 & 646 & 3.59 & -8.59 & $<0.001$ \\
\hline Income/person (minimum salary/person) & 727 & 0.61 & 645 & 0.85 & -7.36 & $<0.001$ \\
\hline Breast feeding period(months) & 977 & 3.84 & 939 & 3.95 & -1.07 & $>0.05$ \\
\hline
\end{tabular}


Table 3 - Crude RRs for main exposures, converted to dichotomous variables.

\begin{tabular}{|c|c|c|}
\hline Variable & Comparison & $\mathrm{RR}(95 \% \mathrm{Cl})$ \\
\hline Fruits and greens hygiene & other care $\mathrm{x}$ disinfected & $4.75(2.84-8.05)$ \\
\hline Refrigerator ownership & no $x$ yes & $3.39(2.71-4.24)$ \\
\hline Water domestic reservoir existence & no $x$ yes & $3.29(2.62-4.13)$ \\
\hline Way water withdrawn from dug well & manual x pump & $3.00(0.74-13.16)$ \\
\hline Feces disposal from swaddle & other $\mathrm{x}$ toilet/latrine & $2.94(2.19-3.94)$ \\
\hline Water supply source & other source $\mathrm{x}$ public network system & $2.78(1.51-5.18)$ \\
\hline Superficial presence of wastewater in street & yes $x$ no & $2.74(2.27-3.32)$ \\
\hline Refuse storage & other $\mathrm{x}$ refuse package & $2.51(2.05-3.06)$ \\
\hline Hand hygiene after defecation & never/low frequency $x$ frequent & $2.34(1.84-3.06)$ \\
\hline Bathroom existence & no/outside $\mathrm{x}$ one or more & $2.15(1.69-2.73)$ \\
\hline Flooding in lot & yes $x$ no & $2.11(1.75-2.56)$ \\
\hline Rat presence & $>$ once a semester $\mathrm{x}<$ once a year & $2.08(1.72-2.52)$ \\
\hline Refuse disposal & other $\mathrm{x}$ public collection & $1.99(1.61-2.48)$ \\
\hline Wastewater disposal & other $\mathrm{x}$ public collection system & $1.97(1.63-2.37)$ \\
\hline Hand hygiene before eating & never/low frequency $x$ frequent & $1.92(1.48-2.50)$ \\
\hline Cockroach presence & $>3$ months a year $x<$ one month a year & $1.74(1.45-2.09)$ \\
\hline Well water quality complaint & yes $x$ no & $1.67(0.35-7.22)$ \\
\hline Refuse collection frequency & 2 times a week $x 3$ times a week & $1.66(1.30-2.11)$ \\
\hline Fly presence & $>3$ months a year $x<1$ month a year & $1.59(1.29-1.96)$ \\
\hline Drinking water care & no $x$ yes & $1.55(1.33-2.14)$ \\
\hline Domestic reservoir coverage & no $x$ yes & $1.52(1.00-2.31)$ \\
\hline Mosquito presence & all time $x<6$ months a year & $1.48(1.23-1.78)$ \\
\hline Pooling in lot & yes $x$ no & $1.46(1.19-1.80)$ \\
\hline Chlorination in dug well & no $x$ yes & $1.29(0.18-6.94)$ \\
\hline Public network water shortage & yes $x$ no & $1.24(1.03-1.49)$ \\
\hline Contact with nearby stream water & yes $x$ no & $1.22(0.54-2.79)$ \\
\hline Domestic reservoir cleaning & never $\mathrm{x}$ sometimes & $1.19(0.88-1.61)$ \\
\hline Near stream existence & yes $x$ no & $1.14(0.94-1.37)$ \\
\hline Wastewater network blockage & yes $x$ no & $1.11(0.75-1.65)$ \\
\hline Public network water complaint & yes $x$ no & $1.03(0.66-1.61)$ \\
\hline Dug well coverage & no/inadequate $x$ adequate & $0.96(0.24-4.36)$ \\
\hline Fruit and greens hygiene & no $x$ yes & $0.64(0.30-1.36)$ \\
\hline
\end{tabular}

inclusion criteria for cases, in order to allow a house visit. Cases identified in participating clinics whose domicile was not located by the interviewers, were excluded from the investigation. In consequence, it is unlikely that a squatter or a child living in a unregistered house would be included in the studied sample. Selection criteria for controls required permanent address in Betim.

Among the several exposures and confounding factors studied, after the multiple adjustment by logistic regression, only 16 dichotomous comparisons showed significant values for the relative risk, reaching up to 2.87 of magnitude (point estimate), as present in Table 4. This fact suggests a strong co-linearity between the environmental sanitation and the hygienic variables and the presence of several confounding factors.

It should be noted that the effect modification term is included only in a model that has both of the corresponding main effects. This is because these terms can be interpreted as effect modifiers only when the corresponding main effect terms are contained in the model. This is the general rule in model building: higherorder terms are included in a model only when the corresponding lower-order terms are present ${ }^{14}$.

Some of the results are in accordance with the literature. Superficial presence of wastewater in street as risk for diarrhea can be seen as an analogous result to studies concerning lack of latrines 32221635 . An inadequate management of domestic refuse showed an odds ratio of 2.48 for infantile diarrhea in Nigeria ${ }^{18}$ and a similar result was also observed in Brazil' ${ }^{21}$. Vector presence, mainly flies, was associated to diarrhea in studies carried out in Thailand ${ }^{43}$ and in Myanmar ${ }^{42}$. Relationship between hygiene practices and infantile health was identified in several investigations, like those developed in Bangladesh ${ }^{46} 1324$, USA ${ }^{28}$, Brazil ${ }^{5}$ and Philippines ${ }^{4}$. Moreover, inadequate feces disposal from swaddle was found to be significantly associated with infantile diarrhea in studies developed in the Philippines ${ }^{3}$ and Bangladesh ${ }^{43}$. 


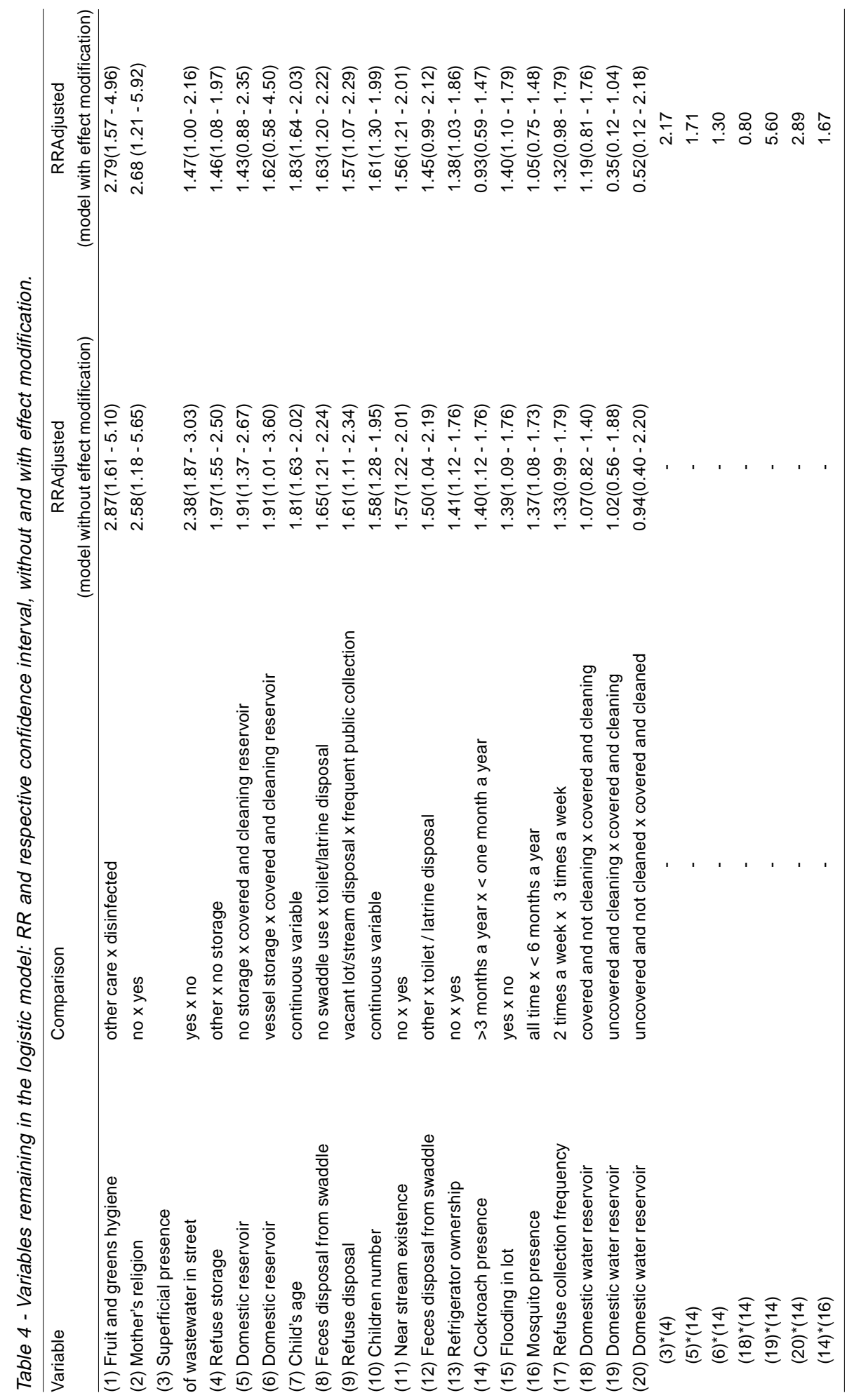


There are several descriptions in the literature of water supply association with health ${ }^{11} 121544$, while other studies do not show any association, for example an investigation in Panama ${ }^{39}$. The importance of quantity of water consumption on health conditions has also been demonstrated ${ }^{44}{ }^{19}$. In this study, the lack of association between several aspects of water supply and health can be explained by: 1) the very low population exposure to the absence of public water supply (1.6\%), due to the high population coverage and 2) to the practice, among Betim inhabitants, of clandestine connection to the public network, observed in the study. This situation reveals an effective nonexistence of exposure.

Albeit references of the health importance of domestic water storage and recommendation for its improvement can be found in the literature ${ }^{37}$, studies that quantify these effects were not identified. Similarly, previous references regarding a health effect of a nearby stream and flooding of rainwater in the lot were also not identified.

The possible limitations of this study findings include: 1) the fact that $29 \%$ of the total cases identified were excluded from interview; however, there is no evidence of any relationship between these exclusions and the exposures studied. A chi-square test, comparing the proportion of cases at participating Health Institutions, showed that the proportion of exclusions was statistically different only for two of them. Both were small Institutions, responsible for a low proportion of cases (1.8 and $4.1 \%)$. Indeed, this limitation would result in an underestimation of the established risks;2) the source of controls, represented by the register used by the municipality for housing taxes, could exclude the informal city that is supposedly more exposed to the lack of environmental sanitation measures. This effect was minimized by the updated municipal file used in this study and the strategy of displacement to the house at the left when the assigned house did not have a child under five years old. This fact was very frequent and allowed the inclusion of the unregistered houses, since slums are very integrated to the urban design of the formal city, in Betim. This possible limitation implies in an overestimation of the risks; and 3) the lag of about three months between cases and controls interview. As control selection did not presume disease definition and the environmental and behavioral exposures studied have a long duration pattern, this time difference probably did not imply in bias in the disease or exposure information. Besides, cases and control interview were conducted in the rainy season.

According to the results of the reliability test, variables related to public environmental sanitation conditions and house characterization - such as reservoir existence and conditions - are more reliable, since direct observation for validation of the answers was carried out. As a consequence, information related to personal and domestic habits were less reliable.

Generalization of the study results seems to be possible for similar urban areas, analogous in size, socioeconomic conditions and public services. It is also possible to visualize that a priority setting for intervention, based on the adopted design, can be a feasible approach. From this point of view, generalization of the present method, adjusted to a specific situation, reveals an important issue: the epidemiological design used inclusive case-control or case-cohort - proves to be valid, since some potential bias on the control group selection, frequent in traditional case-control studies, can be avoided. However, some simplifications, like a smaller sample size, the investigation of a smaller number of confounding variables and the dichotomization of variables in the analysis phase, can be utilized.

The main conclusion of this investigation suggests that an important impact on health status of Betim's children can be achieved by implementation of environmental sanitation measures and hygiene education programs.

Finally, this study also enables the conclusion that infantile diarrhea has multiple and complex determinants. Environmental factors, associated to the lack of appropriate public urban services, poor hygiene practices and social determinants play an important role in transmission of this disease.

\section{ACKNOWLEDGEMENTS}

This research was funded through grants from the Fundação de Amparo à Pesquisa do Estado de Minas Gerais (FAPEMIG), the Conselho Nacional de Desenvolvimento Científico e Tecnológico (CNPq) and the PróReitoria de Pesquisa da Universidade Federal de Minas Gerais" The Municipal Prefecture of Betim offered all the logistic support needed.

\section{REFERENCES}

1. Alam N, Wojtyniac B, Henry FJ, Rahaman MM. Mother's personal and domestic hygiene and diarrhoea incidence in young children in rural Bangladesh. International Journal of Epidemiology 18: 242-247, 1989.

2. Aziz KM, Hoque BA, Hasan KZ, Patwary MY, Huttly SR, Rahaman MM, Feachem RG. Reduction in diarrhoeal diseases in children in rural Bangladesh by environmental and behavioural modifications. Transactions of the Royal Society of Tropical Medicine and Hygiene 84: 433-438, 1990.
3. Baltazar JC, Solon FS. Disposal of faeces of children under two years old and diarrhoea incidence: a case-control study. International Journal of Epidemiology 18: S16-S19, 1989.

4. Baltazar JC, Tiglao TV, Tempongko SB. Hygiene behaviour and hospitalized severe childhood diarrhoea: a case-control study. Bulletin of the World Health Organization 71: 323-328, 1993.

5. Blake PA, Ramos S, MacDonald KL, Rassi V, Gomes TA, Ivey C, Bean NH, Trabulsi LR. Pathogen-specific risk factors and 
protective factors for acute diarrheal disease in urban Brazilian infants. Journal of Infectious Diseases 167: 627-632, 1993.

6. Blum D, Feachem RG. Measuring the impact of water supply and sanitation investments on diarrhoeal diseases: problems of methodology. International Journal of Epidemiology 12: 357-365, 1993.

7. Briscoe J, Feachem RG, Rahaman MM. Measuring the impact of water supply and sanitation facilities on diarrhea morbidity: prospects for case-control methods. World Health Organization, Geneva, 1985.

8. Briscoe J, Feachem RG, Rahaman MM. Evaluating health impact: water supply, sanitation, and hygiene education. International Development Research Centre, Ottawa, 1986.

9. Brussow H, Rahim H, Barclay D, Freire WB, Dirren H. Nutritional and environmental risk factors for diarrhoeal diseases in Ecuadorian children. Journal of Diarrhoeal Diseases Research 11: 137-142, 1993.

10. Campos Filho N, Franco EL. MULTLR user's manual. Ludwig Institute for Cancer Research, São Paulo, 1988.

11. Chambers LW, Shimoda F, Walter SD, Pickard L, Hunter B, Ford J, Deivanayagam N, Cunningham I. Related Articles, Links Estimating the burden of illness in an Ontario community with untreated drinking water and sewage disposal problems. Canadian Journal of Public Health 80: 142-148, 1989.

12. Chute CG, Smith RP, Baron JA. Risk factors for endemic giardiasis. American Journal of Public Health 77: 585-587, 1987.

13. Clemens JD, Stanton BF. An educational intervention for altering water-sanitation behaviors to reduce childhood diarrhea in urban Bangladesh. I. Application of the case-control method for development of an intervention. American Journal of Epidemiology 125: 284-291, 1987.

14. Collett D. Modeling Binary Data. Chapman and Hall, London, 1991.

15. Courbot MCG, Beraud AMC, Gouandjika I. et al. A cohort study of enteric campylobacter infection in children from birth to two years in Bangui (Central African Republic). Transactions of the Royal Society of Tropical Medicine and Hygiene 84: 122-125, 1990.

16. Daniels DL, Cousens SN, Makoae LN, Feachem RG. A casecontrol study of the impact of improved sanitation on diarrhoea morbidity in Lesotho. Bulletin of the World Health Organization 68: 455-463, 1990.

17. Dean AG, Dean JA, Burton AH, Dicker RC. Epi Info, version 5.01; a word processing, database, and statistics program for epidemiology on micro-computers. Center of Disease Control, Atlanta, 1990.

18. Ekanem EE, Akitoye CO, Adedeji OT. Food hygiene behaviour and childhood diarrhoea in Lagos, Nigeria: a case-control study. Journal of Diarrhoeal Diseases Research 9: 219-226, 1991.

19. Esrey SA, Collett J, Miliotis MD, Koornhof HJ, Makhale P. The risk of infection from "Giardia lamblia" due to drinking water supply, use of water, and latrines among preschool children in rural Lesotho. International Journal of Epidemiology 18: 248-253, 1989.

20. Fleiss JL. Statistical methods for rates and proportions. John Wiley \& sons, New York, 1981.

21. Gross R, Schell B, Molina MCB et al. The impact of improvement of water supply and sanitation facilities on diarrhea and intestinal parasites: a Brazilian experience with children in two low-income urban communities. Revista de Saude Publica 23: 214-220, 1989.
22. Guerrant RL, Kirchoff LV, Shields DS et al. Prospective study of diarrheal illnesses in Northeastern Brazil: patterns of disease, nutritional impact, etiologies, and risk factors. Journal of Infectious Diseases 148: 986-997, 1983.

23. Heller L. The state-of-the-art of epidemiological investigation on the field of environmental sanitation. Revista Engenharia Sanitaria e Ambiental 2: 176-189, 1997.

24. Henry FJ, Rahim Z. Transmission of diarrhoea in two crowded areas with different sanitary facilities in Dhaka, Bangladesh. Journal of Tropical Medicine and Hygiene 93: 121-126, 1990.

25. Hosmer DW, Lemeshow S. Applied logistic regression. John Wiley \& Sons, New York, 1989.

26. Jennings R, Person R. Using Access for Windows. Editora Ciência Moderna Ltda, Rio de Janeiro, 1993.

27. Kahn HA, Sempos CT. Statistical methods in epidemiology. (Monographs in epidemiology and biostatistics; Oxford University Press, New York, v. 12), 1989.

28. Laborde DJ, Weigle KA, Weber DJ, Kotch JB. Effect of fecal contamination on diarrheal illness rates in day-care center. American Journal of Epidemiology 138: 243-255, 1993.

29. Landis JR, Koch GG. The measurement of observer agreement for categorical data. Biometrics 33: 159-174, 1977.

30. Lonergan S, Vansickle T. Relationship between water quality and human health; a case study of the Linggi river basin in Malaysia. Social Science and Medicine 33: 937-946, 1991.

31. Magnani RJ, Mock NB, Bertrand WE, Clay DC. Breast-feeding, water and sanitation, and childhood malnutrition in the Philippines. Journal of Biosocial Science 25: 195-211, 1993.

32. Manun'ebo MN, Haggerty PA, Kalengaie M, Ashworth A, Kirkwood BR. Influence of demographic, socioeconomic and environmental variables on childhood diarrhoea in a rural area of Zaire. Journal of Tropical Medicine and Hygiene 97: 31-38, 1994.

33. Mantel N, Haenszel W. Statistical aspects of the analysis of data from retrospective studies of disease. Journal of the National Cancer Institute 22: 719-748, 1959.

34. Mertens TE, Fernando MA, Cousens SN, Kirkwood BR, Marshall TF, Feachem RG. Childhood diarrhoea in Sri Lanka: a case-control study of the impact of improved water sources. Tropical Medicine and Parasitology 41: 98-103, 1990.

35. Mertens TE, Jaffar S, Fernando MA et al. Excreta disposal behaviour and latrine ownership in relation to the risk of childhood diarrhoea in Sri Lanka. International Journal of Epidemiology 21: 1157-1164, 1992

36. Mickey J, Greenland S. A study of the impact of confounder selection criteria on effect estimation. American Journal of Epidemiology 129: 125-137, 1989.

37. Mintz ED, Reiff FM, Tauxe RV. Safe water treatment and storage in the home: a practical strategy to prevent waterborne disease. Journal of the American Medical Association 273: 948-953, 1995.

38. Rodrigues L, Kirkwood BR. Case-control designs in the study of common diseases: updates on the demise of the rare disease assumption and the choice of sampling scheme for controls. International Journal of Epidemiology 19: 205-213, 1990.

39. Ryder RW, Reeves WC, Singh N, Hall CB, Kapikian AZ, Gomez $B$, Sack RB The childhood health effects of an improved water supply system on a remote Panamanian island. American Journal of Tropical Medicine and Hygiene 34: 921-924, 1985. 
40. Schlesselman JJ. Case-control studies: design, conduct, analysis. (Monographs in Epidemiology and Biostatistics, Oxford University Press, New York, Vol. 2, 1982.

41. The Cobb group. Running Microsoft Excel 4. 3rd ed. Makron Books, São Paulo, 1993.

42. UKM, Khin M, Wai NN, Hman NW, Myint TT, Butler T Risk factors for the development of persistent diarrhea and malnutrition in Burmese children. International Journal of Epidemiology 21: 10211029, 1992.

43. Vathanophas K, Indrasukhsri T, Bunyaratabandhu P, Suthienkul $\mathrm{O}$, Varavithy A. The study of socioeconomic, behavioural and environmental factors related to diarrhoeal diseases in children under 5 in congested areas of Bangkok Metropolis. Journal of the Medical Association of Thailand 69: 156-162, 1986.

44. Victora CG, Smith PG, Vaughan JP, Nobre LC, Lombardi C, Teixeira AM, Fuchs SC, Moreira LB, Gigante LP, Barros FC Water supply, sanitation and housing in relation to the risk of infant mortality from diarrhoea. International Journal of Epidemiology 17: 651-654, 1988.

45. Wilkinson L, Hill M, Welna JP, Birkenbeuel GK. SYSTAT for windows - version 5 edition: statistics. 2nd edition Evanston, IL: SYSTAT, Inc, 1992.

46. World Bank. Measuring of the health benefits of investments in water supply. (Report n. PUN 20). Washington: World Bank, 1976. 